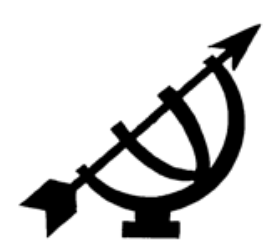

\title{
Deepening democracy and enhancing multi-level governance: deficiencies of and prospects for local government ward committees in South Africa
}

\author{
P.W. Heydenrych \\ School for Social and Government Studies \\ Potchefstroom Campus \\ North-West University \\ POTCHEFSTROOM \\ E-mail: Pieter.Heydenrych@nwu.ac.za
}

\begin{abstract}
Deepening democracy and enhancing multi-level governance: deficiencies of and prospects for local government ward committees in South Africa
\end{abstract}

The South African local government system has a number of shortcomings, two of which relate to the role of local government in the deepening of participatory democracy and the position of local government in a system of multi-level governance. In this article, it will be posited that a lack of depth and quality in local democracy compromises the system of intergovernmental relations. Against this background, views on participatory democracy as a theoretical background will be investigated and the development and deficiencies of the ward committee system considered.

In order to contextualise the mechanism of local participation, selected international examples of public participation will be considered and an indication of the negative and positive aspects of these cases given. The South African system of intergovernmental relations will be investigated in order to show the importance of local government and public participation therein. Thereafter, suggestions will be made regarding the improvement of public participation in local government in order to adhere to the requirements of democracy and, as a result, to enhance and legitimise the system of intergovernmental relations. 


\section{Opsomming}

\section{Verdieping van demokrasie en versterking van multivlakregering: tekortkomings en vooruitsigte vir plaaslike regeringswykskomitees in Suid-Afrika}

Die Suid-Afrikaanse plaaslike regeringstelsel openbaar verskeie tekortkomings. Twee spesifieke aspekte is plaaslike regering se rol in die verdieping van deelnemende demokrasie en plaaslike regering se posisie in 'n stelsel van multivlak regering. In hierdie artikel word van die standpunt uitgegaan dat 'n gebrek aan diepte en gehalte in plaaslike demokrasie gevolglik ook die stelsel van interowerheidsverhoudings kompromitteer. Teen hierdie agtergrond word ondersoek ingestel na beskouings van deelnemende demokrasie as teoretiese agtergrond waarna aandag geskenk word aan die ontwikkeling van die wykskomiteestelsel en die tekortkomings word ook aangedui.

Ten einde die meganisme van plaaslike deelname te kontekstualiseer, word enkele internasionale voorbeelde van plaaslike deelname oorweeg en ook aangedui wat die tekortkomings en positiewe aspekte in daardie gevalle is. Die Suid-Afrikaanse stelsel van interowerheidsverhoudings word ondersoek om die belang van plaaslike regering en openbare deelname daarin aan te dui, waarna voorstelle aan die hand gedoen word om openbare deelname in plaaslike regering te verbeter ten einde aan die vereistes van demokrasie te voldoen en ook om sodoende die stelsel van interowerheidsverhoudings te versterk en te legitimeer.

\section{Introduction}

The South African local government system is a response to a history of exclusion and undemocratic governance, within a constitutionally entrenched framework for the development of an inclusive democratic local government. Within a climate of crisis in local government (about half of municipalities are part of an assistance programme called Project Consolidate), the implementation of the local government system has highlighted various shortcomings. Two specific matters receive attention in this article: local government's role in deepening participatory democracy and its position in a system of multi-level governance (interdependence between a multitude of actors in the governance process).

Both of these matters relate to the South African Constitution (SA, 1996). Chapter 3 of the Constitution provides for co-operative government (which finds expression through a system of intergovernmental relations) and Chapter 7 provides for local govern- 
ment. Indeed, the objects of local government found in this chapter include the encouragement of the involvement of communities in local government, which is taken further in the Local Government Municipal Systems Act, 32 of 2000 (SA, 2000) in which municipalities are defined as a combination of political structures and administration as well as the community, thereby cementing local government in a system of multi-level governance.

The contention of this article is that only through effective, efficient and meaningful democratic public participation can democratic local government and meaningful multi-level governance be realised. It is argued that in both these arenas the institutional mechanisms and practical implementation have not been adequate in deepening the democratic system the Constitution envisages. In other words, the normative aspects of democracy have not been realised in practice. Related to this point, Nsingo and Kuye (2005:748) refer to Ntalaja's analysis of the concept of democracy, indicating that democracy is a political concept premised on value, process, and practice.

The value premise indicates that democracy is a moral value demanded by all freedom-loving human beings. It is an aspiration of all who want a better socio-political order that protects humanity and advances the interests of the latter. (Nsingo \& Kuye, 2005:748.)

Public participation in local government has been legislatively facilitated primarily through a system of ward committees. Several strategies for public participation are also acknowledged, but these fall outside the scope of this article, which focuses on ward committees as an institution as opposed to strategies for public participation (cf. Theron, 2005:126-128). The contents of the National Ward Committee survey 2004/2005 (SAD, 2005a) indicate that these committees are not functioning effectively and that their implementation has, at least in some cases, perhaps been a matter of compliance rather than substance. Indeed, as the only structured public participation vehicle, they suffer from limited function, debatable composition, and questionable recognition (Hollands, 2003:25).

This raises the question of the meaningfulness of public participation, specifically by means of ward committees, in the deepening of democracy. In the arena of multi-level governance, it can be asserted that if the substantiality of local democratic public participation is questioned, the validity of outcomes in a process where public participation is regarded as a "stakeholder", should be questioned. 
Certainly, the South African government acknowledges the role of citizens in the intergovernmental relations process.

Citizens also play an important role in identifying their own development priorities. Councillors encourage citizens to participate through Ward Committees and public meetings called by the council ... This promotes accountability in the IDP (Integrated Development Planning) process, public participation in the process of analyzing the spatial economy, and consensus on growth and development priorities. (SAD, 2007:6.)

Yet, it would appear that substantive guidance from government is deficient regarding the manner in which this should be accomplished in ward committees.

This article therefore engages with the concept of public participation as a prerequisite for democracy in a postapartheid environment, specifically through the institution of municipal ward committees, which should be vehicles allowing citizens equal and transparent opportunity in exercising their democratic rights in the local sphere of government. The conclusion of the article thus suggests an improved means for democratic public participation in local government with a view of:

- involving citizens in the performance of local public duties;

- widening the basis of political participation;

- safeguarding pluralism at various levels;

- facilitating problem-orientated grass roots approaches which are appreciated by citizens;

- strengthening the restrictions and controls (checks and balances) of political power which is indispensable in a democracy (Hofmeister, 1997:20).

\section{Theoretical views of democratic public participation and establishing parameters for public participation}

In considering the issue of participation in democracies, the general perception of what is articulated by scholars, as well as the public and policymakers, is a formalistic understanding of the concept. Generally, reference is made to voting in elections, taking part in referenda, interest group participation, as well as the type of structures established within a legal framework for the purposes of public participation. It is suggested that it is this formalistic understanding 
that needs to be challenged in the minds of policymakers and those that ought to participate, in other words, all citizens.

In order to place a discussion of public participation in a theoretical context, it is necessary to consider the aspects pertaining to the relationship between democracy and public participation. Magstadt (2006:89) places the people at the centre of his conception of democracy: "A different way of thinking about democracies is to focus on the role of the people under different models - after all, democracy is by definition a form of rule by the people." Magstadt (2006:89-92) then discusses Hudson's models of democracy, referring to protecttive democracy, developmental democracy, pluralist democracy, and participatory democracy. The main function of government in a protective democracy is to safeguard the liberty of citizens. Hudson views that such a democracy exists for free and competitive individuals to have maximum freedom to pursue material wealth, and few demands are placed on citizens to participate beyond voting. Developmental democracy focuses on the development of virtuous citizens, and broad participation is regarded as essential but citizens do not actually take part in decision-making. Magstadt (2006:91) finds that:

Hudson's model of pluralism, however, emphasizes the tendency of pluralistic democracy to evolve into a hierarchical sociopolitical order dominated by political elites. Thus, pluralistic democracy is inherently oligarchic: in a society that places a high priority on business, entrepreneurship and the amassing of personal wealth the natural result is social and economic inequality.

The model of participatory democracy may be considered as the closest to a practical model of direct democracy. Today, it is accepted that direct democracy is not a practical answer to the question of the people governing. However, participatory democracy is based on the conviction that apathy is a conditioned response.

Deprived of opportunities to participate in meaningful ways, people will naturally tune out or get turned off. The key to a vibrant citizenry - and therefore to a healthy democracy - is active participation on a large scale across a wide spectrum of issues. Participatory democracy goes farther, arguing, not only that citizens would participate actively in politics given the chance but also that they should participate - that is, that they have a right to do so. (Magstadt, 2006:91.) 
On participation, Parry and Moyser (2000:442) state that: "In any attempt to measure the extent of democracy, the degree of popular political participation must constitute one of the indices." Dahl (as quoted in Parry \& Moyser, 2000:443) proposes that it is only when liberalisation (public contestation: competition for office and political support) occurs in tandem with participation that one can speak of democratisation. The conception of democracy is therefore critical, and it can be agreed that contemporary institutions serve rather to discourage such ideals, and so participationists look for changes in the structures of politics to widen citizen involvement.

Barber (2000:447) echoes the importance of participation, stating that "[s]elf-government is carried on through institutions designed to facilitate ongoing participation in agenda-setting, deliberation, legislation, and policy implementation". He defines strong democracy as follows:

... strong democracy in the participatory mode resolves conflict in the absence of an independent ground through a participatory process of ongoing, proximate self-legislation and the creation of a political community capable of transforming dependent private individuals into free citizens and partial and private interests into public goods (Barber, 2000:447-448).

He also responds to the limitations of representative democracy in suggesting that strong democracy has the potential of transcending the limitations of representation without yielding such defining characteristics of democracy as liberty, equality and social justice (Barber, 2000:448). He emphasises that through strong democracy, these characteristics take on a richer and fuller meaning. He also addresses the self-generating nature of participation by essentially arguing that community builds participation and participation builds community, thereby addressing another critical concern about participation, that is, the sustainability of participation.

However, Dahl sounds a warning. Pateman (2000:473) notes that Dahl suggests that political activity is a prerequisite for polyarchy, but that the relationship is an extremely complex one. Dahl refers to "authoritarian" personalities that are most frequently found in lower socio-economic groups. It is argued that a rise in political activity that brings this group into the political arena might cause a decline in norm-consensus necessary for the polyarchy - "therefore, an increase over the existing amount of participation could be dangerous to the stability of the democratic system" (Pateman, 2000:473). 
The above discussion can be brought into the realm of participatory developmental local government. Theron (2005:112) emphasises four public participation principles as formulated in the Manila Declaration (1989). These principles refer to sovereignty residing with the people, the enabling role of government for people to set and pursue their own agenda, people's right to control their own resources and hold government accountable, and those who assist people with their development must recognise that they are participating in support of the people's agenda.

It can be concluded from the above discussion of theoretical views on democracy and participation that the two concepts are inextricably linked and that at the centre of these two concepts are the people and their development.

\subsection{Typology of public participation}

It is possible to isolate different types of participation that may deepen the democratic process. Nsingo and Kuye (2005:750-751) reconfigure such a typology from the World Bank (2003). The typology is reflected in the table below (cf. a discussion on typologies in Theron, 2005:114-119).

\section{Table 1: Typology of participation}

\begin{tabular}{|l|l|l|}
\hline $\begin{array}{l}\text { Type of } \\
\text { participation }\end{array}$ & Action & Comment \\
\hline Persuasion & $\begin{array}{l}\text { ON: Communities are } \\
\text { informed and manipulated, } \\
\text { but have no real input or } \\
\text { power. }\end{array}$ & $\begin{array}{l}\text { A local authority (agency) } \\
\text { presents people with an } \\
\text { idea/initiative to gain support. } \\
\text { People are made to see rea- } \\
\text { lity according to the agency. } \\
\text { This is one-way communica- } \\
\text { tion (information dissemina- } \\
\text { tion) in which the agency ma- } \\
\text { nages or leads the develop- } \\
\text { ment process. }\end{array}$ \\
\hline Mobilisation & $\begin{array}{l}\text { FOR: Others set the agen- } \\
\text { da and determine the pro- } \\
\text { cess. }\end{array}$ & $\begin{array}{l}\text { The agency involves people } \\
\text { in order to induce contribution } \\
\text { of labour or funds to supple- } \\
\text { ment agency resources and } \\
\text { keep costs down. This is also } \\
\text { done to increase people's } \\
\text { sense of ownership and re- } \\
\text { sponsibility for maintenance. }\end{array}$ \\
\hline
\end{tabular}




\begin{tabular}{|c|c|c|}
\hline Consultation & $\begin{array}{l}\text { FOR/WITH: Others ana- } \\
\text { lyse the information and } \\
\text { decide on the course of } \\
\text { action. }\end{array}$ & $\begin{array}{l}\text { Communities are consulted to } \\
\text { provide better information for } \\
\text { decisionmakers. The views } \\
\text { communities hold may or } \\
\text { may not be considered. Often } \\
\text { consultation increases deci- } \\
\text { sion input and leads to de- } \\
\text { cisions that are more appro- } \\
\text { priate. }\end{array}$ \\
\hline Participation & $\begin{array}{l}\text { FOR/WITH: Citizens influ- } \\
\text { ence decisions and share } \\
\text { responsibility for the out- } \\
\text { comes, but often the agen- } \\
\text { da is set by others. }\end{array}$ & $\begin{array}{l}\text { Communities contribute to } \\
\text { decision-making. All share } \\
\text { the responsibility of making } \\
\text { decisions, but often coun- } \\
\text { cillors and public officials } \\
\text { have more influence, parti- } \\
\text { cular where expertise is } \\
\text { needed for strategic issues. }\end{array}$ \\
\hline Collaboration & $\begin{array}{l}\text { WITH: There is partner- } \\
\text { ship, joint action, and co- } \\
\text { production (working with } \\
\text { others to set priorities and } \\
\text { participate in implementing } \\
\text { on a basis of equality with } \\
\text { other stakeholders). }\end{array}$ & $\begin{array}{l}\text { A local authority is bound by } \\
\text { statutes and political com- } \\
\text { mitment to give weight to the } \\
\text { views of the citizens, al- } \\
\text { though "partnerships" are } \\
\text { often unequal. Participating } \\
\text { communities are implicated in } \\
\text { the outcomes and share the } \\
\text { risk that these might differ } \\
\text { from those intended; thus, } \\
\text { they share accountability. }\end{array}$ \\
\hline $\begin{array}{l}\text { Collective } \\
\text { action/Self- } \\
\text { management/ } \\
\text { Empowerment }\end{array}$ & $\begin{array}{l}\text { BY: Communities are in } \\
\text { control, with little or no } \\
\text { input by others. }\end{array}$ & $\begin{array}{l}\text { Communities decide for } \\
\text { themselves and carry full } \\
\text { responsibility. They are em- } \\
\text { powered and so may act } \\
\text { without local authority input. } \\
\text { The danger is that poor com- } \\
\text { munities lack the resources to } \\
\text { solve their problems without } \\
\text { external support, which com- } \\
\text { promises their authority and } \\
\text { autonomy. }\end{array}$ \\
\hline
\end{tabular}

Van der Waldt (2007:30-32) also indicates the different levels of participation possible, referring to Kalk (1996) and Van Houten (1992) in this regard. The conclusion is that participation can be viewed as a continuum, with information provision at the one end and empowerment or self-management at the other. 
In summary, participatory democracy can be viewed as a healthy form of democracy, perceived to be closer to the core of democracy than the other forms of democracy as mentioned earlier. Furthermore, participation is a democratic right and changes in the structures of politics are required to enhance citizen involvement. Also, when democratisation is fundamental, as is the case in South Africa, liberalisation must be closely associated with participation in order to consolidate democracy. Democratisation can be argued to be a process that builds on itself in developing a community, cultivating public interest as opposed to fostering isolated individualism. Lastly, public participation must be a balanced phenomenon, the exercise of which must not move towards anarchy and away from democracy. Therefore, the continuum of public participation is important; there must be a considered development moving from persuasion to empowerment, noting that simultaneous application of different levels of participation in the same or different settings is possible as well.

\section{Concept, context and implementation of local government ward committees}

Following on the discussion of theoretical views on democracy and participation, attention should be given to the institution of ward committees where the concepts of democracy and participation should be practised. It is important to note that the understanding of South African local government has changed dramatically since 1994. One such change pertaining to local government has been a move away from a limited form of democracy reserved essentially for white citizens towards local governance and participatory democracy. Another change is the conceptualisation of local government as a sphere governing in its own right rather than an administrative level of government, as was the case previously. This history of South African local government must thus be seen as a background influencing a process of democratisation and attempting to instil a culture of participation.

In this article it is accepted that the South African government endorses public participation in municipal governance as an important element in the promotion of local democracy. In the greater context of a South African state founded on principles of democracy and participation by all, local government is also being transformed to reflect these values. Democracy is thus understood as not only concerning formal elected representation, but also concerning a continuous cycle of interaction between elected leaders and the 
community. The aim of this interaction is to address the needs and concerns of the community and strengthen civil society, thereby facilitating responsive government.

\subsection{Policy development}

Following on the constitutional imperative of an inclusive local democracy in the Department of Constitutional Development (SADC, 1997a:9), it is stated that:

Throughout the world, municipalities have come to appreciate that the relation between government and those who are governed is as important as government itself. This is what is meant when people speak of the shift from government to governance. Governance is a way of governing. It takes the views and interests of those affected by government more seriously than in the past. The 'governed' refers to the community at large. This includes individuals, community organisations and businesses, trade unions and NGOs. Municipalities have realised that they need to involve the community and all its constituent parts in the functioning of government. Relationships, partnerships and alliances have therefore become much more important for local government than in the past.

Denters and Rose (2005:253) refer to Leach and Pery in their discussion of governance, stating that:

... the traditional notion in which 'local government is "what the council does"' had to be replaced by a conception in which it is conceded that public decision-making concerning local issues 'increasingly involves multi-agency working, partnerships and policy networks which cut across organizational boundaries' in essence governance.

The Department of Constitutional Development's Green Paper on Local Government (SADC, 1997b) articulates evolving policy pertaining to participatory democracy in the local sphere more clearly. The Green Paper states that municipal councils have a central role to fulfil in enhancing local democratic participation, both as a means of rebuilding local communities and as a contribution to nation building. Furthermore, it is argued that the contact between municipalities and communities need not be limited to election and representation. On the contrary, increased citizen involvement will increase municipalities' ability to effectively shape viable human settlements (SADC, 1997b:63).

Significantly, the Green Paper states: 
Democratic participation in government enhances effective governance by:

- building human capital and strengthening democratic cultures in communities;

- enhancing official responsiveness by enabling public interests to be clearly expressed by communities themselves;

- promoting government legitimacy by ensuring transparency;

- creating conditions for smooth policy implementation by facilitating an understanding of policy objectives and constraints, and incorporating citizen preferences and concerns into the design of policy programmes;

- channelling independent energy, ideas and sometimes resources into civic objects; and

- improving citizens' knowledge of the governing processes and its constraints, and so fostering an understanding of the need for prioritisation. (SADC, 1997b:64.)

The White Paper on Local Government focuses on public participation as a central theme. The term ward committees is specifically used within the context of metropolitan government systems (SADC, 1998:64-65). The reasoning in this regard appears to suggest that ward committees were regarded as a mechanism allowing for greater interaction with the metropolitan municipality by communities within the context of a single tier metropolitan local government system. The policy on ward committees put forward in the White Paper corresponds closely with the provisions relating to ward committees that can be found in the Local Government Municipal Structures Act, 117 of 1998 (SA, 1998). Concerning the role of ward committees, it is stated in the White Paper that the central role of ward committees is the facilitation of local community participation in decisions that affect the local community, the articulation of local community interests, and the representation of these interests within the government system. Ward committees thus provide a structured channel of communication between geographic communities and their political representatives. Moreover, well-functioning ward committees should provide every resident with a local point of access to municipal government and strengthen the accountability of ward councillors to local residents. 
The provisions in the Local Government Municipal Structures Act, 117 of 1998 (SA, 1998) provide the legal basis for ward committees. Section 72(3) provides some guidance of what the role of ward committees is: "The object of a ward committee is to enhance participatory democracy in local government." Concerning the functions and powers of ward committees, section 74 provides that a ward committee may make recommendations on any matter affecting its ward. In addition, a ward committee has the duties and powers as the municipal council may delegate to it.

After commencing with the establishment of ward committees in 2001, draft guidelines for the establishment and operation of municipal ward committees were presented at the National Conference on Ward Committees and published in 2003 (SAD, 2003). These draft guidelines were promulgated in 2005 as final guidelines without any substantive changes (SA, 2005b). In the draft guidelines, a comprehensive provision deals with the functions and powers of ward committees and a number of duties and powers that may be delegated to ward committees were suggested. The most relevant functions are:

a) To serve as an official specialised participatory structure in the municipality;

b) To create formal unbiased communication channels as well as cooperative partnerships between the community and the council. This may be achieved as follows:

i) Advise and make recommendations to the ward councillor on matters and policy affecting the ward.

ii) Assist the ward councillor in identifying conditions, challenges and the needs of residents.

iii) Spread information in the ward concerning municipal affairs such as the budget, integrated development planning, service delivery options and municipal properties.

iv) Receive queries and complaints from residents concerning municipal service delivery, communicate it to council and provide feedback to the community on council's response.

v) Ensure constructive and harmonious interaction between the municipality and community through the use and co-ordination of ward residents and other community development forums.

vi) Interact with other forums and organisations on matters affecting the ward. 
c) To serve as a mobilising agent for community action. This may be achieved as follows:

i) Attending to all matters that affect and benefit the community.

ii) Acting in the best interest of the community.

iii) Ensure the active participation of the community in:

aa) Service payment campaigns;

bb) The integrated development planning process;

cc) The municipality's budgetary process;

dd) Decisions about the provision of municipal services; and

ee) Decisions about by-laws.

iv) Delimitate and chair zonal meetings. (Department of Provincial and Local Government, 2003:8-9.)

It is clear from the above that the role and functions of ward committees depend on the participation element and do not take on the role ascribed to the elected representative or the employed municipal official. In addition, this can be compared to the participation typology referred to earlier. The role of ward committees as presented in the draft guidelines therefore needs to be understood within a contextualised framework as an instrument of public participation within a broader context of municipal (and multi-level) governance. All functions performed by ward committees must also fit into this framework. In summary, ward committees should participate, communicate and mobilise.

It should be noted that national guidelines cannot prescribe the details of the manner in which these functions must be fulfilled. Municipalities as independent organs of state have a very important role to fulfil in this regard and should provide for the role and functions of ward committees innovatively within the specific municipal context. Scope for diversity of implementation therefore exists.

\subsection{Implementation challenges}

The implementation of the ward committee system has been an uneven process. In 2004, the Department of Provincial and Local Government undertook an unpublished survey to determine the state of the implementation of the ward committee system. Questionnaires were sent to municipalities attempting to gauge a 
number of aspects relating to ward committees. Responses indicated the following main powers and functions of ward committees:

- prioritisation and submission of projects;

- determination of community needs;

- scrutiny of proposed budgets and inputs;

- projects for IDPs (also review of IDPs and Performance Management System);

- liaison between council and community;

- communication;

- reporting;

- complaint centre;

- local economic development;

- "Work as a support team";

- mobilisation of community;

- develop and implement ward sectoral programmes;

- inputs on budget and provision of services;

- assist in campaigns such as Water Wise;

- information dissemination;

- recommendations on street names and land use planning;

- enhance culture of payment; and

- proposing various schemes for community upliftment (SAD, 2004:9-10).

The above list generally corresponds with the role and functions foreseen in policy instruments, such as relevant legislation and the draft guidelines. It is noted, however, that the functions as described differ from municipality to municipality. This should not be viewed with concern, however, as each municipality differs. Rather, what is important is that ward committees fulfil the participatory role that is essential in the conceptualisation of democracy as suggested earlier. 
Some municipalities did report difficulties in ensuring the effective functioning of ward committees. Many are faced with budgetary and financial constraints. However, in some instances, a lack of commitment undermines participatory democracy; for example, some of the remarks made by municipalities were the following: "Some meetings not held as there is a lack of buy-in from communities to attend as well as members" (SAD, 2004:38); "Two councillors are never available or never call a meeting and one councillor cannot get people to attend a meeting" (SAD, 2004:24).

From the above, it is evident that the role of ward committees is not being fulfilled in all cases. There is certainly a lack of understanding of the role of ward committees in some instances; in others there is apathy, both from the community and councillors, and in some cases, there is a lack of commitment from municipalities. One municipality reported as follows: "Availability of time, unemployment and poverty are concerns which have a higher priority, than attending a meeting that from their (the community) point of view has nothing to offer." (SAD, 2004:42.) In response to this, the question could be asked: Should the community not be capacitated to use these committees as tools in addressing poverty and unemployment, that is for their own development in reference to the Manila Declaration mentioned earlier?

More recently, the Centre for Public Participation highlighted a number of concerns in a research report (Buccus et al., 2007). These include unresponsiveness from local government, lack of clarity on whether commitment to public participation is a genuine passion, consensus that mechanisms are working poorly, which is all ascribed to a lack of clear policy, financial support and training (Buccus et al., 2007:23). The report found that ward committees have an uneven spread, and generally limited impact, and are ineffective in securing improved service delivery. It further found that public participation is awarded little consideration in decisions with almost no perceptible outcome, public participation mostly legitimises higher decisions, and civil society is weak in authority and power (Buccus et al., 2007:24). These findings can be compared with the participation typology presented in Table 1 . The report concludes that public participation is not a challenge of political will, but rather one of practical implementation; in other words, it is a challenge to those who want to participate but cannot do so. The report proposes that "[w]ith better policy, organisation and resources we can meet this challenge, and develop real public participation which improves delivery, builds local governance and deepens democracy" (Buccus et 
al., 2007:26). To this it can be added that "real" participation must be quality participation and not only organisation and resources supporting formal structures.

Esau (2007:195) and Oldfield (2008:491) confirm the challenges experienced concerning public participation generally and in relation to ward committees.

\section{Selected international examples of local public participation mechanisms and successes and failures of implementation}

The preceding discussion highlighting the nature and deficiencies of public participation through ward committees in South Africa paves the way for exploring ways of addressing deficiencies. In this section, some international examples of public participation in local governance are considered with the aim of comparison to the South African system in order to identify similarities, differences, successes and shortcomings. Two diverse countries are investigated, viz. Zimbabwe, which has much in common with South Africa (such as a British colonial history, a liberation struggle, and poverty of a large percentage of the population) and Venezuela, which has far less in common with South Africa.

\subsection{Zimbabwe}

Nsingo and Kuye (2005) explore democratic participation as a fundamental concept for improving service delivery in rural local government in Zimbabwe. Their focus is specifically on the rural district councils - Zimbabwe's rural communities are estimated at $65 \%$ of the population. They contextualise their discussion in terms of the importance of public participation. Although it might seem surprising considering the state of Zimbabwe today, a directive was issued in 1984 stating that "there was need for a comprehensive and more democratic system of involving people vertically and horizontally in the process of planning and effecting their development, thus providing Government with a viable channel for receiving and assessing the developmental needs and priorities of the district, ward and village areas within the province" (Nsingo \& Kuye, 2005:752-753). Despite this, it is common to find practices that minimise the role of communities in local governance. Nsingo and Kuye (2005:755) argue that communities are used to being dictated to, and that rural communities are ill-informed, resulting in minimised public participation. 
The structures established for the purpose of development and participation in Zimbabwe represent a system of intergovernmental relations, which is of importance to the contention in this article. These structures include Village Development Committees (VIDCOs), Ward Development Committees (WADCOs), District Development Committees (DDCOs) and Provincial Development Committees (PDCOs). The VIDCOs submit their community plans to the WADCOs, after which they are submitted to the DDCOs and then the PDCOs. Eventually, they are submitted to the central planning agency, the National Planning Commission in the Ministry of Finance. In this way, decision-making on programmes and projects of a local nature is expected to originate from the grass roots and filter through the political system (Nsingo \& Kuye, 2005:755).

Through the above-mentioned model of development and grass roots participation, elected local structures are given the chance to participate in programme prioritisation (Nsingo \& Kuye, 2005:755). Their functions include the following:

- identification and articulation of village needs;

- coordination and forwarding of village needs to the WADCO;

- coordination and co-operating with government extension workers in the operations of development planning;

- coordination and supervision of all activities relating to production and general development of the village area; and

- organising the people to undertake projects that require a considerable workforce.

Nsingo and Kuye, unfortunately, do not overtly refer to Zimbabwe's current political (social and economic) tragedy and its impact on local governance. Their focus is on the structural aspects of democratic participation, which results in limited analysis of the effectiveness of these structures. Nsingo and Kuye (2005:758) do, however, propose that councillors include one item of public participation and community empowerment on their agenda, policy discourse models be adopted and local institutions, such as NGOs and CBOs, that actively encourage local self-determination be promoted. These proposals appear to suggest that local participation mechanisms are not functioning optimally at present, which explains the emphasis on proactively keeping the matter on agendas. 


\subsection{Venezuela}

Gibbs (2006:265) refers to the "Bolivarian revolution" in Venezuela indicating that it represents an all-out assault on neo-liberal doctrine. He states that "[a] key aspect of the revolution has been the effort to revitalize citizenship through the construction of mechanisms for public participation in decision-making, particularly aiming at the poor majority". Although Gibbs' contribution can be placed in a somewhat different context than that of this article, it is felt that the importance of the Venezuelan case can be found in the exploration of affording vitality to public participation. Gibbs (2006:266) argues that the "Venezuelan process points to the possibilities of and challenges to the effort to deepen democracy (improving its quality) and suggests that there are both support and practical challenges to build national and transnational processes ...".

Gibbs places his contribution against the background of globalisation and neo-liberalism. Exactly because of this context, there might be value in comparison with South Africa. South Africa might also be labelled "neo-liberalist" in its current policies and evidence of the "crisis of neo-liberalism" may be seen in the leadership change (perhaps even ideology struggle) within the ruling African National Congress. It is suggested in this article that Gibbs (2006:268) may have been correct in contending that "[a]t the root of these problems lies the issue of redistribution".

In addressing the issue of redistribution, a key aspect of the Bolivarian Revolution has been an effort to revitalise citizenship through the construction of mechanisms for public participation in decisionmaking, particularly aiming at the poor majority. It is these issues that are of interest in this article. Also a multi-level governance context is evident:

The Bolivarian Revolution aims to reconnect politics and economics concretely by building participatory, democratic processes from the community level up and building redistributive mechanisms into policy making from the state level down ... President Chávez noted: 'This concept entails, among other things, the people's political participation in the control of the state and its decision-making process, a reform of public powers based on the Bolivarian constitution, a fairer redistribution of the oil income and the land, the creation of an economic infrastructure and formulation of revolutionary social policies that enable change toward a humanistic society based on full respect for citizenship rights: healthcare and education for all, decent employment, land for those who toil it, food security, 
sports and culture and a genuinely leading role played by the people within the national political dynamics.' (Gibbs, 2006: 270.)

The Venezuelan Constitution focuses specifically on two areas of fundamental rights with equal standing to civil and political rights: health care and education. An example of participation mentioned by Gibbs (2006:272) in relation to health care is that neighbourhoods form local health committees that manage the clinics, and several small clinics work directly out of a converted section of a family dwelling. The process of achieving the stated health care goals requires active participation of communities, who are encouraged to examine the health of their communities as part of a larger project of social transformation. This is achieved through local government, various types of neighbourhood associations, and health and school committees. These groups are responsible for identifying their community's needs, for contributing to designing programmes to solve local problems, and for evaluating programmes. In this sense, community members themselves are required to take responsibility for leadership in health care and education so that they themselves are accountable (Gibbs, 2006:273).

The Venezuelan government's approach to education is an integrated one, meaning that their philosophy is that a vibrant democracy requires the active participation of citizens who are well nourished, healthy and educated. Schools, for example address nutritional issues, and cafeterias are run by "mother collaborators" from the community who have attended a government-sponsored intensive course on nutrition. In addition, local governments have been active in creating spaces for community engagement, such as local assemblies, neighbourhood associations, and sports and social arenas (Gibbs, 2006:275).

In considering the examples of Zimbabwe and Venezuela, it is evident that because Zimbabwe has a political history similar to South Africa, an understanding of the politics of Zimbabwe is more complete. It would appear that Zimbabwe's public participation mechanisms also do not adequately support the structures that are in place, and similarities in the level of participation can be discerned. Compare, for example the functions of structures mentioned above, such as identification, articulation, and co-ordination. Venezuela affords more hope in terms of what quality participation (deepening democracy) may mean, placing the exercise against some of the broader systemic challenges faced by both South Africa and Zimbabwe, such as globalisation and the neo-liberal paradigm. Also, an 
aspect that must be noted is the role public participation fulfils in terms of the multilevel governance context and intergovernmental relations systems.

\section{The context of multilevel governance: the intergovernmental relations system}

Having considered public participation within the theoretical context of democracy, specifically reviewing the ward committee phenomenon and considering international examples of participation, consideration should be afforded to the importance of public participation in a multilevel governance context, in order to take public participation to a logical conclusion in the policy process. Considering what has been said in the introduction to this article and the observances of an intergovernmental context in the discussed international examples, it is suggested that the logical benefit of deepening democracy through ward committees is improved democratic input to the intergovernmental relations system. In this article, the focus is placed on local government's positioning within the South African intergovernmental relations dispensation.

The following figure provides a simple description of the manner in which the spheres of the South African state are organised. In this figure, public participation is viewed as a foundation for the successful operationalisation of intergovernmental relations. 
Figure 1: Public participation and intergovernmental relations

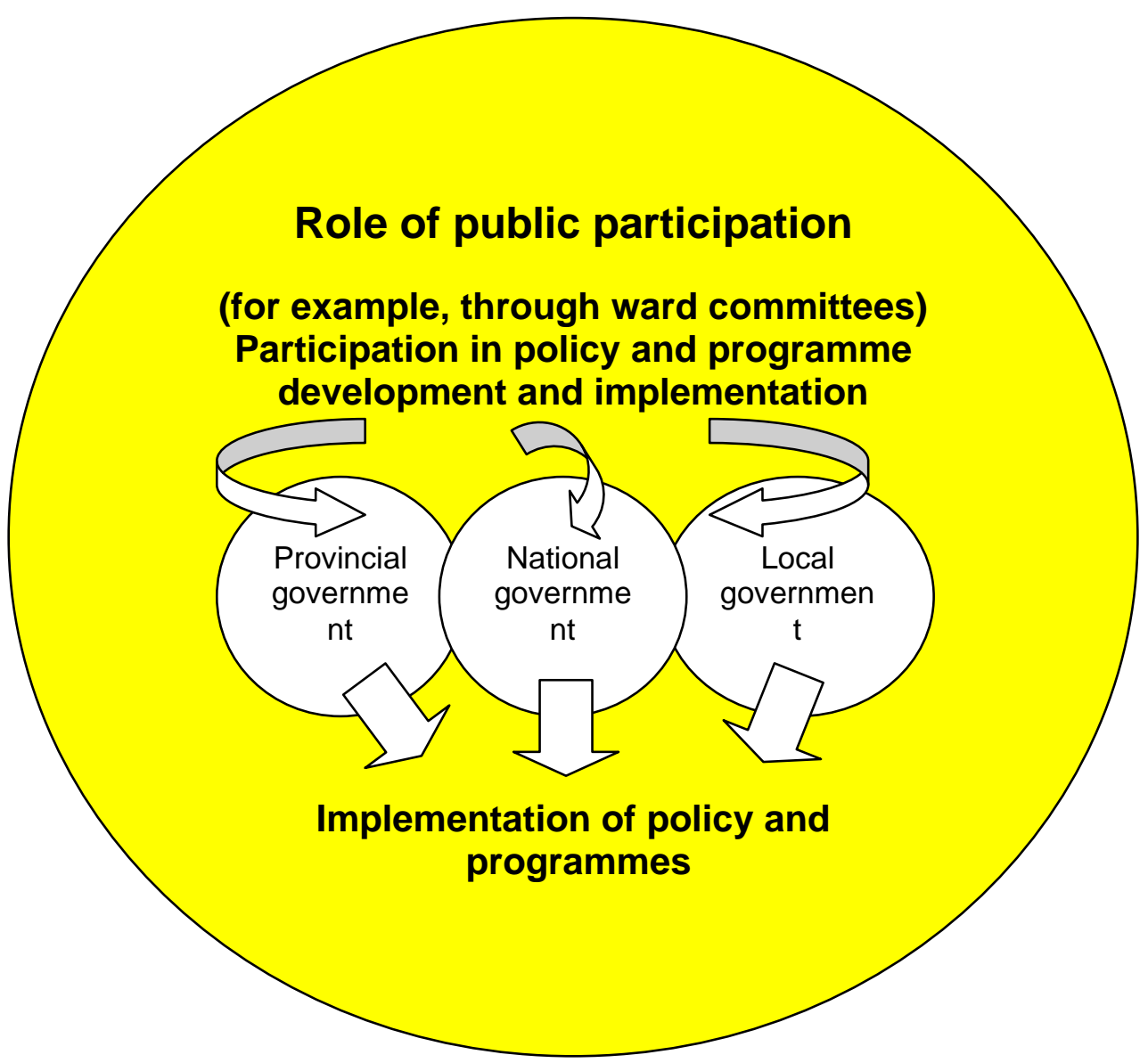

Chapter 3 of the Constitution defines the relationship between the spheres of government as one of distinctiveness, interrelatedness and interdependence (SA, 1996). All spheres are constitutionally bound by the principles of co-operative governance and must foster friendly relations, assist and support one another, consult and inform one another, co-ordinate their actions and legislation, and avoid legal proceedings against one another. In countries with federal characteristics, it is inevitable that there will be overlaps and interdependence when governments exercise their powers. Therefore, the various organs of government generally need to consider each other as partners, in order to minimise conflict and create an environment of adaptability to changing circumstances. The South African government views intergovernmental relations as an evolving system of institutional co-operation that seeks to address the relations of equality and interdependence as defined by the Constitution. The importance of intergovernmental relations is underlined by, among other things, the matter of popular accountability and grass roots 
pressure translating into key objectives, such as effective service delivery and accountability.

The importance of local government within the intergovernmental relations dispensation was highlighted by former President Thabo Mbeki in his State of the Nation address (3 February 2006). He stated the following:

Integration of planning and implementation across the government spheres is ... one of the prime areas of focus in our programme for the next term of local government. In this regard we will be guided by the Intergovernmental Relations Framework Act. We must in practice respect the system of cooperative governance, and within this context ensure that we empower local government to discharge its development and service delivery obligations. (SAD, 2006a:1.)

\subsection{Development of the intergovernmental relations system}

In the January 2003 cabinet Lekgotla endorsed the view that the central challenge in intergovernmental relations is to ensure that the machinery of government functions in a more integrated way and more efficiently to deliver services to communities. Following on this decision, the Intergovernmental Relations Framework Act, No. 13 of 2005 (SA, 2005) provides the institutional framework to co-ordinate distinctive responsibilities and forge a coherent government for the country as a whole. This institutional framework provides for intergovernmental structures as well as for intergovernmental consultation and discussion. Although they are not executive decisionmaking bodies, intergovernmental structures may adopt resolutions or make recommendations in terms of agreed procedures.

Intergovernmental relations processes seek the alignment of public policies and priorities. A vital focus is strategic planning and budgeting, i.e. the clear articulation of political priorities and the budgeting for their realisation. The key processes in this regard are the Medium Term Strategic Framework (MTSF) and Medium Term Expenditure Framework (MTEF), which is informed by the MTSF. The MTSF sets out the way government has translated its mandate into medium-term priorities and the combination of programmes that will be used to achieve its objectives. The MTEF details the government's three year rolling expenditure and revenue plans for national and provincial departments. Provincial growth and development strategies (PGDS) are articulated by provincial executive councils and should involve national priorities and IDPs developed by each municipality with public participation. All the elements of planning 
must form part of a broad planning framework that includes a planning cycle and calendar.

Despite the above development of the intergovernmental relations system over the past years, and the operationalisation of the mentioned structures, a number of challenges have been identified:

- The need for continued strengthening of intergovernmental planning around common national objectives.

- Complexity of structural reform.

- The need to clarify revenue and expenditure assignment in a dynamic context.

- Addressing uneven capacity and capability in the provincial and local spheres of government.

- Co-ordinating policy issues that cut across traditional policy fields, portfolios and mandates located in several institutions.

- Achieving responsive, accessible and efficient government.

- Co-ordinating intergovernmental planning in the local government sphere.

- Addressing the challenges of poverty and underdevelopment. (SAD, 2006b.)

The integrated nature of the South African governance system, connecting all three spheres of government through political and technical structures in the process of governing, is clear from the above summary of the intergovernmental relations system. Structurally there is even an acknowledgement of public participation through, for example, the IDP process.

The structural nature of this system (consider also the process focus, such as pertains to planning) can be criticised. It would appear that very little is provided in terms of the substance or quality of what happens in the intergovernmental relations system. It is a rather mechanical exercise. Edwards (2008:66) states the following:

Various efforts, such as the establishment of intergovernmental structures, procedures and tool kits have been initiated by government, but the question remains whether these efforts are sufficient to ensure that effective intergovernmental relations take place in all spheres of government. 
The identified challenges mentioned above support this contention. Consider, for example, the issues of poverty and underdevelopment mentioned above and those specific challenges relating to local government. For example, it can be asked whether the challenge of co-ordinating intergovernmental planning in the local sphere is not a specific obstacle hindering effective multi-level governance and democratic input into the process. It is exactly these challenges that can be addressed by empowered public participation through ward committees.

The interrelatedness of all of this, however, also means that if the system malfunctions in one sphere, the failure will affect the whole system. For this reason, inadequate public participation in the local sphere will lead to poor quality governance in all spheres, whilst an inadequate model of public participation and lack of sufficient support for public participation from government will be devastating for public participation and ultimately for democratisation and democracy.

\section{Conclusion: suggestions for democratic local public participation in South Africa}

It is clear from the discussion in this article that there is a general framework for public participation in South Africa. A commitment to the concept as evidenced by policy development, legislation and the establishment of structures is clear. Even in comparison with the example of public participation in Venezuela, similarities in concepts can be recognised. What is of concern is that the application of the concept of public participation through ward committees has been:

- Structurally hampered: A basic structure was developed and legislated, however, the legislation on this matter is so limited in scope that no substantial guidance can be given to ward committees on what it is and what it should do. No attempt has been made to develop this legislation further. Also, the focus has been on structural establishment rather than on developing the qualities of public participation. Esau (2007:188) notes that: "[d]espite these formal arrangements, however, media reports, political and social theorists and even government point to the inability of citizens to participate in a meaningful way".

- Insufficiently vigorous: The available resources and the bureaucratic support of ward committees have been mostly marginal. Also, once the committees have been established, the motivation to fulfil their functions appears diminished. 
- Only superficially committed: The level of commitment both in terms of values and through resources has been limited. The possibility that politicians undermine ward committees is relevant as well, but falls outside the scope of this article.

- Insufficiently integrated into the system of intergovernmental relations. Although provision is made, as indicated earlier in this article, it seems that public participation remains a marginal "stakeholder" in the process and the politics of intergovernmental relations has been party-politically (representative democracy) driven.

- Hampered by ideological constraints: The dualities of the ruling party's ideology has hampered a quality deployment of the ward committee system.

- Not always aligned with social realities: A singular model of implementation does not take cognisance of the different realities and permutations of realities in South African society, such as differences among provinces, municipalities, suburbs and communities, as well as levels of poverty and education. Esau (2007:188189) states that "[w]e witness increasing apathy, protests by the poor against the slow pace of service delivery, the introduction of approaches and strategies that ignore the realities of the poor and a growing chasm between the rich and the poor" and "... as a culture of democratic governance has yet to take full root in the country, the opinions and views of the poor must adequately be expressed and welfare fully achieved".

The need is thus for the further transformation of public participation to reach a level where it can begin to consolidate the democratic gains made in South Africa. This is particularly so if considered against some critical issues not interrogated in this article, such as the rich-poor divide, poverty in itself, social upliftment, community development, education, the racial divide, the possible dilemma of the economic system within the neo-liberal context, and the ideological backbone of the South African interpretation of public participation.

In order to achieve a model of quality local participation through ward committees, it is therefore necessary to consider at least the following in the further development of democratic local participation:

- A re-orientation of the basic understanding of ward committees (such as the value dimension of democracy) to improve their community-building and democratising qualities (cf. Esau, 2007: 
193). "He [Gaventa] argues that the creation of new institutional designs of participatory governance is only inclusive when it allows for participatory spaces that serve to provide and sustain countervailing power."

- The determination of a model for the allocation of functions to ward committees, moving local public participation towards empowerment on the scale of public participation, as well as contributing to the improvement of the intergovernmental relations system.

- The composition of ward committees (which is currently structured in a particular, and restrictive manner, for example the guidelines currently displaying a bias towards institutional stakeholders), in order to empower the people at the centre of democracy and participation.

- The education of ward committee members and the community in preference to "training" as often applied in connection with ward committees.

- Quality integration and purpose in the intergovernmental relations system beyond a process approach.

- Integration with other social networks, particularly of health care and education, as evident in the Venezuelan case discussed earlier.

- A model for focused and acknowledged support of ward committees from government.

- A model allowing for greater diversity in various settings and differing social circumstances.

It is likely that the application of the considerations listed above will deepen the integrated and interrelated features of the South African democracy, by bringing quality to the relationship between citizens, local government, other spheres of government and the state as a whole.

\section{List of references}

BARBER, B.R. 2000. Strong democracy. (In Blaug, R. \& Schwarzmantel, J., eds. Democracy: a reader. Edinburgh: Edinburgh University Press. p. 447451.) 
BUCCUS, I., HEMSON, D., HICKS, J. \& PIPER, L. 2007. Public participation and local governance. Research report by Centre for Public Participation in association with Human Sciences Research Council and School of Politics, University of KwaZulu-Natal, Jun. http://www.cpp.org.za/docs/ reports/2007/lg-report0507.pdf Date of access: 26 Mar. 2009.

DENTERS, B. \& ROSE, L.E. 2005. Towards local governance? (In Denters, B. \& Rose, L.E., eds. Comparing local governance: trends and developments. Hampshire: Macmillan. p. 246-262.)

EDWARDS, T. 2008. Cooperative governance in South Africa, with specific reference to the challenge of intergovernmental relations. Politeia, 27(1):65-85.

ESAU, M.V. 2007. Citizen participation and the poor: a participatory approach to achieving political, social and economic freedom? Politikon, 34(2):187203.

GIBBS, T. 2006. Business as unusual: what the Chávez era tells us about democracy under globalization. Third world quarterly, 27(2):265-279.

HOFMEISTER, W. 1997. Democracy: definitions and concepts in the context of the transformation of political systems. (In Hofmeister, W. \& Scholz, I., eds. Traditional and contemporary forms of local participation and selfgovernment in Africa. Johannesburg: Adenauer. p. 11-21.)

HOLLANDS, G. 2003. The performance of ward committees. (In Hologram. The best of Hologram 2001-2003: issues and practice in South African local government. Cape Town: Nolwazi. p. 21-27.)

MAGSTADT, T.M. 2006. Understanding politics. Belmont: Wadsworth.

NSINGO, S.A.M. \& KUYE, J.O. 2005. Democratic participation for service delivery in local government in Zimbabwe: humanising structural configurations and legal provisions. Journal of public administration, 40(4):744-760.

OLDFIELD, S. 2008. Participatory mechanisms and community politics: building consensus and conflict. (In Van Donk, M., Swilling, M., Pieterse, E. \& Parnell, S., eds. Consolidating developmental local government: lessons from the South African experience. Cape Town: University of Cape Town Press. p. 487-500.)

PARRY, G. \& MOYSER, G. 2000. More participation, more democracy? (In Blaug, R. \& Schwarzmantel, J., eds. Democracy: a reader. Edinburgh: Edinburgh University Press. p. 442-446.)

PATEMAN, C. 2000. Participation and democratic theory. (In Blaug, R. \& Schwarzmantel, J., eds. Democracy: a reader. Edinburgh: Edinburgh University Press. p. 469-474.)

SA

SAD

see SOUTH AFRICA. SADC

see SOUTH AFRICA. Department of Provincial and Local Government.

see SOUTH AFRICA. Department of Constitutional Development.

SOUTH AFRICA. 1996. Constitution of the Republic of South Africa, Act 108 of 1996. Pretoria: Government Printer.

SOUTH AFRICA. 1998. Local government: Municipal Structures Act, 117 of 1998. Pretoria: Government Printer.

SOUTH AFRICA. 2000. Local government: Municipal Systems Act, 32 of 2000. Pretoria: Government Printer. 
SOUTH AFRICA. 2005. Intergovernmental Relations Framework Act, 13 of 2005. Pretoria: Government Printer.

SOUTH AFRICA. Department of Constitutional Development. 1997a. South Africa's local government: a discussion document. Pretoria.

SOUTH AFRICA. Department of Constitutional Development. 1997b. Green Paper on Local government. Pretoria.

SOUTH AFRICA. Department of Constitutional Development. 1998. White Paper on Local government. Pretoria.

SOUTH AFRICA. Department of Provincial and Local Government. 2003. Draft Guidelines for the establishment and operation of municipal ward committees. (Proclamation, no. 2649, 2003.) Government gazette, 25621:2, 24, Oct.

SOUTH AFRICA. Department of Provincial and Local Government. 2004. Report: survey on the establishment and operation of ward committees 2004/2005. Pretoria. (Unpublished.)

SOUTH AFRICA. Department of Provincial and Local Government. 2005a. National Ward Committee Survey 2004/05. Pretoria.

SOUTH AFRICA. Department of Provincial and Local Government. 2005b. Guidelines for the establishment and operation of municipal ward committees. (Proclamation, no. 965, 2005.) Government gazette, 27699, 24 Jun.

SOUTH AFRICA. Department of Provincial and Local Government. 2006a. Intergovernmental Relations Framework Act: evolution and practice. Pretoria.

SOUTH AFRICA. Department of Provincial and Local Government. 2006b. Commonwealth local government forum: experiences of co-operative governance in South Africa. 24 Jul. [PowerPoint presentation]

SOUTH AFRICA. Department of Provincial and Local Government. 2007. Working together for development: understanding intergovernmental relations. Pretoria.

THERON, F. 2005. Public participation as a micro-level development strategy. (In Davids, I., Theron, F. \& Maphunye, K.J., eds. Participatory development in South Africa: a development management perspective. Pretoria: Van Schaik. p. 111-132.)

VAN DER WALDT, G. 2007. Fostering local democracy. (In Van der Waldt, G., ed. Municipal management: serving the people. Cape Town: Juta. p. 2446.)

\section{Key concepts:}

democracy

intergovernmental relations

local government

public participation

\section{Kernbegrippe:}

demokrasie

interowerheidsverhoudings

openbare deelname

plaaslike regering 